IJ§ER

ISSN: 2149-5939
International Journal of Social Sciences and Education Research

Online, http://dergipark.gov.tr/ijsser

Volume: 2(3), 2016

\title{
Performance of strategic alliance management: Coordination-cooperation cycle
}

\author{
Hicham Achelhi ${ }^{1} \quad$ Patrick Truchot ${ }^{2}$
}

Received Date: 27 / 02 / 2016

Accepted Date: 22 / 03 / 2016

\begin{abstract}
Facing environmental changing and those of competition dynamic, new types of organizations have been advanced as a response to new challenges. These types of organization based on cooperation between enterprises have been lately developed. The aim of this article is to understand cooperation in order to reduce the risks of their fail. Thus, understanding the governance of alliances can provide critical insights into how such ties can be better managed: we focus on the coordination-cooperation relationship. The first part of this article, we will give a theoretical back ground about cooperation and coordination. A conceptual framework of the coordination/cooperation process is developed. In the second part, we develop our vision high lightens the existence of a process coordination-cooperation which is sequenced and cycled. That allows achieving objectives of strategic alliance and also partners' objectives. For improving the performance and the success of the alliance project, it is necessary that the coordination-cooperation process go through different strategic level of different partners engaged in the alliance project.
\end{abstract}

Keywords: Cooperation, Coordination, Strategic Alliance Governance, Alliance performance

\section{Introduction}

Strategic alliances are « voluntary arrangements between firms involving exchange, sharing, or co-development of products, technologies, or service » (Gulati, 1998). They are the cooperation and collaboration of two or more independent companies each of which has its own culture, own agenda, and strategy. Cooperation is defined as coordinated actions taken by exchange parties to achieve mutually beneficial behavior in terms of flexibility, information exchange, and shared problem solving (Anderson and Narus, 1990; Heide and Miner, 1992; Morgan and Hunt, 1994). We noticed that each partner has its own project in the overall project. We define the alliance like a multi organisation with multi projects management (Achelhi and Al., 2013).

Doz and al., (1998) affirme that when they asked participants, ten years ago, in their executive seminars whether their firms needed alliances, the answer was most often no. They thought that they had resources and know-how to complete and win. For the question « who can still run these races alone? The answer today is: nobody » (Doz and al., 1998). This phenomenon has been gaining momentum for the last two decades. The main reasons are the globalization revolution : changes are realized in very short periods of time, destructive technologies and innovations, excessive competition, the technological improvement and the revolution of information, and the increasing power of the consumer (Kotler and Caslione, 2011)

\footnotetext{
${ }^{1}$ Abdelmalek Essaadi Un., Faculty of Science \& Technology, Morocco, achelhihicham@yahoo.fr ${ }^{2}$ INPL-National School of Ind. Systems Engineering, France. patrick.truchot@ensgsi.inpl-nancy.fr
} 
Achelhi, H., Truchot, P. (2016). Performance of strategic alliance management: Coordination-cooperation cycle. International Journal of Social Sciences and Education Research, 2 (3), 708-721.

To the question « Do firms benefit from entering strategic alliances? » according to Gulati (1998), the answer is not always positive. Some researches have shown that there is no causality relationship between cooperation and performance of the company especially in the joint venture cases.

Inter-organizational cooperation in networks is becoming increasingly important, and as such there are numerous companies which participate in various networks to gain a competitive advantage. Strategic alliances have quickly become a major strategic tool that few firms can afford to ignore (Rindfleisch, 2000; Teng, 2003; Shah and Swaminathan, 2008). Andersen Consultancy made a survey in which they researched how important it is for companies to have alliances with companies in the same branch of industry; in this survey $17 \%$ of the senior managers indicated that alliances are important, $36 \%$ of these senior managers indicated that alliances will have a vital importance within 10 years (Baldock, 2010). Apple's portfolio of ties with EMI, Google, Salesforce.com, Microsoft, and other firms was key to its success. These ties enabled Apple to focus on its strengths, such as architectural design, while leveraging their partners' resources and market positions (Ozcan and Eisenhardt, 2009); The chairman of Sony Akio Morita pointed out that no corporation is an island that they need each other and that in a globalizing world they are in a way obliged to find ways to cooperate with other companies in order to be able to compete (Yoshino and Rangan, 2000). As a result, « strategic alliance » has become a style of business life for each company irrespective of their sizes (Kiernan,1998)

Alliances have been seen as attractive vehicles through which companies can grow and expand their scope (Harrigan, 1986). Alliances help firms strengthen their competitive position by enhancing market power (Kogut, 1991), increasing efficiencies (Ahuja, 2000), accessing new or critical resources or capabilities (Rothaermel \& Boeker, 2008), entering new markets (GarciaCanal, Duarte, Criado, \& Llaneza, 2002), expand its zone of uncertainty (Crozier et E. Friedberg, 1993 ) and to get the scale's economy (Das and Teng, 2000). Strategic alliances' value-creating potential makes them an important source of competitive advantage (Das \& Teng, 2001; Larsson et al., 1998). By the turn of this century many of the world's largest companies had over $20 \%$ of their assets, and over $30 \%$ of their annual research expenditures, tied up in such relationships (Ernst, 2004). A notable characteristic of this growth has been the increasing diversity of interfere alliances. The report "cooperation for development by the OECD (2006) shows an increase in spending on technical cooperation in several countries in the world between 1989 and 2005. This report shows that in addition to the USA, Germany, France and Japan are the leaders in the field. And in general, from 2001, there is a strong tendency of growth of cooperative relations in all countries.

As a result, a growing number of research and articles treating these kind of companies organisation and seek to show the importance of cooperative agreements. Companies find strategic alliances formation to be a way out in ordre to increase sales and profitability. Doz and al. (1998) pointed out top level executives of companies want to establish strategic alliances:

1. In ordre of obtaining supplementary products and services that they are not able to develop by themselves or to get the complementary goods and services that allow new businesses to develop. Firms search for partners having specialized resources that aren't readily available from others (Doh, 2000). It join Lovallo \& al. , (2003) and Mascarenhas \& al., (2005) for who no firm has all in-house ressources needed, so managers are increasingly using alliances to leverage partners' complementary ressources, especially to do research and development activities. Firms 
Achelhi, H., Truchot, P. (2016). Performance of strategic alliance management: Coordination-cooperation cycle. International Journal of Social Sciences and Education Research, 2 (3), 708-721.

search for partners with resources they lack (Gulati et al., 2000). Thus, a firm's resource profile plays an important role in alliance formation (Stuart, 2000). Partners are complementary if one partner has strengths where the other has weaknesses (Hamel, 1991), thus, the fundamental logic behind complementarity is a logic of differences. For example, Stuart (2000) found that large firms with leading technologies were considered highly valuable partners, particularly for younger and smaller firms often without the resources that could allow them access to such technology.

2. In ordre of cospecializating « the synergistic value creation that results from the combining of previously separate ressources and knowledge sources » (Doz and Al, 1998). Often, firms form alliances to strengthen or extend resources that in turn sustain current competitive advantages or help develop new advantages (Kumar \& Nti, 1998). Searching for access to new resources or know-how through alliances, firms carefully select partners with needed resource profiles and learn by intensifying their relationships with them. In this way, alliances can simultaneously prevent organizational inertia while promoting environmental adaptation (Doz, 1996).

3. And in order to have their companies gain values by bringing together the sources and values of their companies and by learning and internalizing new skills, in particular those which are tacit, for their companies from their competitors. Numerous research assert that learning and acquiring know-how are important rationales for the formation of strategic alliances contributing significantly to alliance outcomes (Dong \& Glaister, 2006; Hamel, 1991; Inkpen \& Beamish, 1997; Lyles \& Salk, 1996). Knowledge has emerged as a central theme in the resource-based and alliance literature and is seen as the strategically most important source of competitive advantage (Conner \& Prahalad, 1996; Grant \& Baden-Fuller, 2004). According to the resource-based view, the competitive advantage of firms arises from their superior capability in transferring and creating knowledge (Foss \& Foss, 2005; Spender, 1996, Grant, 1996). In other words, they suggest that organizations improve their skills to manage a given task by accumulating and applying knowledge relevant to that task, this work emphasizes the role of certain learning processes in building alliance capability. The resource-based perspective suggests that the firm is a collection of heterogeneous resources (tangible and intangible assets that are semi-permanently tied to the company) (Wernerfelt, 1984). Sustained resource heterogeneity is a potential source of competitive advantage (Das \& Teng, 2000a). For example, on the issue of knowledge and learning capabilities, partner characteristics at the alliance inception have been shown to influence the learning process between partners (Ariño \& De la Torre, 1998). Consequently, firms differ significantly in their ability to leverage tangible and intangible complementary resources. Building on Cohen and Levinthal's concept of absorptive capacity, Lane and Lubatkin contend that firms do not have the same ability to learn from all other firms. Firms learn more from those partners with whom they share common knowledge and informational bases (Cohen \& Levinthal, 1990; Lane \& Lubatkin, 1998). Furthermore, alliance portfolio characteristics have been suggested to influence the absorpt ive capacity of firms (George, Zahra, Wheatley \& Khan, 2001).

\section{Purpose and hypothesis}

While alliances can create enormous wealth, they can also become black holes for management time and resources. For Doz and Hamel (1998), few executives have more than a superficial understanding of what drives the economic and competitive consequences of strategic alliances. 
Achelhi, H., Truchot, P. (2016). Performance of strategic alliance management: Coordination-cooperation cycle. International Journal of Social Sciences and Education Research, 2 (3), 708-721.

Many have argued that alliance structure at formation is the key to alliance success. Hence, success is predetermined by the initial combination of ingredients (Doz, 1996) such as partner selection (Wuyts and Geyskens, 2005; Wu et al., 2009) and strategic and organizational congruence (Shane, 1998). Structural factors refer to the various initial factors that partners bring into the strategic alliances. Other proponents have argued that the alliance implementation process and how it evolves over time has more influence on strategic alliance success (Ariño and de la Torre, 1998), i.e. process factors referring to the action pattern that unfolds during the alliance.

Some authors consider that the success of a strategic alliance is determined by achievement of the pursued objectives that were defined in the early stages of the relationship (Bonaccorsi and Piccaluga, 1994; Brockhoff and Teichert, 1995; Phillips et al., 2000).

Searchers have identified coordination as a condition for strategic alliance success (Aaggarwal and al., 2011, Nielsen, 2010; Zollo and Al., 2002). Teams need to first understand a task before they can develop appropriate motivation to complete the task (Kanfer and Ackerman, 1989). Therefore, when a team involved in a handoff does not effectively execute goal alignment processes, the receiving team will not fully understand the task nor have sufficient motivation to commit to its required activities. Instead, the team will act in accord with other priorities it believes to be more salient. Because teams prioritize their own objectives over those of other teams or the organisation (Becker, 1992; Kristof, 1996; Reichers, 1985; Zaccaro and Dobbins, 1989), it is likely that the team on the receiving end of an incomplete handoff will find little reason to cooperate.

Our main aim of this paper is to identify the determining factors of success in strategic alliances. This study examines how can organizations manage different structure of their alliance. It explores the importance of coordination, division of labor and their implementation on alliance success.

In this work, we will discuss two hypotheses:

Hypothesis 1: A planned collective work have two levels: coordination which seek the collective success, and cooperation which seek the individual success. Thus, we can schematize this complementarity between coordination and cooperation by a spiral that connects reflection to realization, whose goal is the achievement of alliance objectives. It is a dynamic vision of collective work.

Hypothesis 2: the alliance success depends on cooperation/coordination quality process

\section{Research methodology}

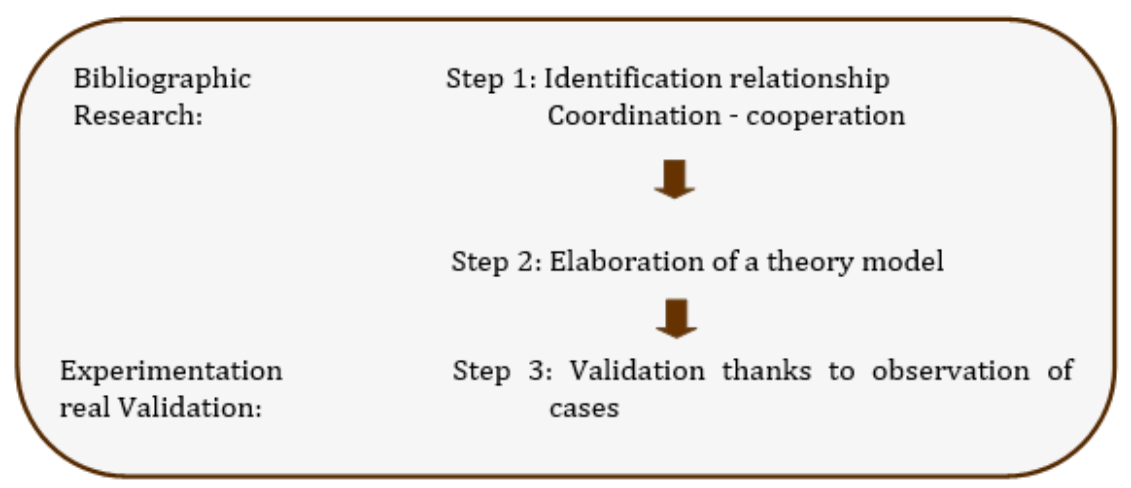

Figure 1. Research Methodology 
Achelhi, H., Truchot, P. (2016). Performance of strategic alliance management: Coordination-cooperation cycle. International Journal of Social Sciences and Education Research, 2 (3), 708-721.

In the first stage, we will perform a bibliographic research in ordre to understand the concept of cooperation and coordination. Then, in the second step, we will develop a theoretical model that allows us a better alliances' understanding, so a better governance of them.

During the third step, we will compare our model to reality in the draft frameworks and observation of alliance projects management.

\section{Coordination}

« Every organized human activity ... gives rise to two fundamental and opposing requirements: the division of labour into various tasks, and the coordination of these tasks to accomplish the activity ». (Mintzberg H., 1980)

Gulati and al., (1998), in ordre to explain the importance of coordination, he asks us to imagine an ideal situation: an alliance is formed between two firms that have complete confidence in each other and face no appropriation concerns whatsoever. Despite this frictionless situation, they must still coordinate the division of labor and the interface of activities and products between them. This creates considerable uncertainty that alliance partners consider at the time they form an alliance and attempt to answer in structuring the relationship. Hierarchical controls can be an effective solution in situations of high anticipated coordination coasts. As noted by (Gulati and Al.,1998) an important basis for hierarchical controls in their ability to provide superior task coordination, especially in situations involving high interdependence and coordination. Dyer and Singh (1998) suggest that coordination in the presence of relational controls is superior and that "self-enforcing safeguards" such as relational controls result in lower transaction costs than using formal controls does. Gulati and Singh (1998) suggest that in innovation contexts "inter-firm trust can be an extraordinary lubricant for alliances that involve considerable interdependence and task coordination between partners."

«Coordination is the process of building programs by gluing together active pieces ». (Carrieri et Gelernter, 1992). Inter organizational coordination is formally defined as the extent of routines to coordinate activities and resources with the alliance partner (Gulati, Lawrence and Puranam, 2005). "Coordination is the process by which an agent reason about its local actions and the (anticipated) actions of others to try and ensure the community acts in a coherent manner, is perhaps the key problem of the discipline of Distributed Artificial Intelligence » (Jennings, 1993).

Coordinate is arranged a set of part following a logical plan for a specific purpose. The synonyms are commonly offered "arrangement", "order", "organization". Coordination is a "rational collective order" (Demeron 2003). Gulati (2012) define coordination as the deliberate and orderly alignment or adjustment of partner's share to the detriment Jointly accomplish achieve goals.

Coordination is broadly understood in the social sciences as the linking, meshing, synchronization, or alignment of actions (Okhuysen and al., 2009). « ... When an agent voluntarily enters into a relationship with and adopts the goal of another agent such that the interdependencies between the agents' activities are managed to achieve the goal...» (Angela Console and al., 2007)

Teams develop 'habitual routines' (Gersick and Hackman, 1990) that make them less open to change. These consistent behaviours enable teams to perform without allocating additional mental and coordinative effort, but as they become more rigid it becomes increasingly difficult for a team to adapt (Arrow et al., 2000). 
Achelhi, H., Truchot, P. (2016). Performance of strategic alliance management: Coordination-cooperation cycle. International Journal of Social Sciences and Education Research, 2 (3), 708-721.

Some researchers have argued that coordination is central to team effectiveness (Stout, sales and Carson, 1994; Kozlowski and Bell, 2003). Stout and al., (1994) find that coordination positively influences dyadic team performance in flight simulated tasks. Without well-coordinated integration and full cooperation, it would be difficult for allied airlines to reduce through-ticket fares through elimination of double marginalization or efficiency gain.

When teams make important decisions, they must coordinate activities among their members to be effective (Stout, Cannon-Bowers, Salas, \& Milanovich, 1999). In addition, when teams or organizations engage in complex and interdependent tasks, a common (or "shared") understanding of the task is tremendously important.

Teams distinguish themselves from other teams by way of their boundaries, internal structures, behaviours, the attitudes of constituent members, the type of resources they obtain and use, specific language, ... Cultural differences also make cognitive differences between these boundary spanners more likely (Berends, Garud, Debackere, \& Weggeman, 2011): they may have different conceptions of required tasks and of the alliance's environment, and may disagree about which task interdependencies and uncertainties are most important, about how much alignment is required or desirable, and about when the right level of alignment has been achieved (Gerwin, 2004)

The coordination challenges created by this heterogeneity can impede the effectiveness of inter-unit collaboration or "integration", even when employees are motivated to undertake collaborative efforts (Kretschmer and al., 2008)

Organizations engage in coordination efforts to manage the task interdependence that can flow a given division of labor (Achelhi and al., 2007; Raveendran and Al, 2012). Coordinating actions is further complicated by the fact that actors cannot assume that their interests and goals are perfectly aligned (McEvily and al., 2003)

A number of researchers present the importance of coordination of alliance activities as a condition of it's success (Zollo and al., 2002; Nielsen, 2010; Aggarwal and Al., 2011). Müller and Dirk (2010) suggest to intensely coordinate the alliance and to be aware of dysfunctional tendencies that erode alliance value. Kale and al. (2002) show the relationship with coordination and alliance success. They investigated this aspect and found that having a dedicated alliance function, which is responsible for overseeing and coordinating a firm's alliance activity, was positively linked to greater alliance success.

In order to meet the coordination requirements and to guarantee a holistic management approach in a multi-alliance environment, many companies have established an 'alliance function' (Dyer et al., 2001; Bamford and Ernst, 2002).

Indeed, firms with the dedicated function achieved a $25 \%$ higher long-term success rate with alliances than firms without the function. The mandate for a dedicated alliance management function is broad, as shown by Dyer et al.(2001) call for it to, “... coordinate all alliance-related activity within the organization and (to institutionalize) processes and systems to teach, share, and leverage prior alliance-management experience and know-how throughout the company." Such an alliance function is also proposed by some authors, although literature on multi-alliance situations normally focuses on specific problems, such as control aspects (Bamford and Ernst, 2002; Platje and Seidel, 1993; Platje et al., 1994; Dyer et al., 2001; Rickert, 1995; Pradel, 1997).

Coordinating mechanism involves the rhythmic patterns of interacting entities and how (if at all) these rhythmic patterns may converge (Bluedorn, 2002). There are two primary properties to 
Achelhi, H., Truchot, P. (2016). Performance of strategic alliance management: Coordination-cooperation cycle. International Journal of Social Sciences and Education Research, 2 (3), 708-721.

these rhythms: that of cycle and pace. The term "cycle" refers to one complete implementation of a repeating phenomenon (Ancona \& Chong, 1996) and "pace" refers to the speed in which the cycles entrain, imposing a boundary condition of sorts for the entrainment of cyclic activity (Bluedorn, 2002). Eisenhardt and Brown (1998) provide an example of pacing when they refer to "time pacing", which is the rhythmic timing of events such as entering a new market.

Researchers differentiate two central coordination tasks of alliance management: inter organizational coordination (governance of individual alliances) and alliance portfolio coordination (integration of all of an organisation's strategic alliance) (Schilke and Goerzen, 2010)

Interorganizational coordination ensures that single alliances are governed efficiently and that the legitimacy of transaction between the partners is enhanced (Kumar and Nti, 1998). The need for coordinating the alliance portfolio is primarily a result of the interdependences between the individual alliances. Alliance portfolio coordination aims to identify these interdependences, avoid duplicate actions and produce synergies among the individual alliances (Banford and Ernst, 2002 ; Hoffmann, 2005). Further alliance portfolio coordination aims to allocate limited resources to alliance projects that allows maximum profit ensuring conflict reduction, which consider a key advantage of alliance portfolio coordination (Parise and Casher, 2003)

Hoffmann (2005) identify four tasks of portfolio management: strategy, monitoring, coordination and establishment of an alliance management system. For this companies need to create a dedicated alliance function.

Different coordinating mechanisms are applied, ranging from strict centralisation to great autonomy of those centres (Gassmann, 1997; Boutellier et al., 1999; Brockhoff, 1998).

Swarts (2004) argues that coordination is based on two events: the ratification of a proposal and the revision and subsequent ratification of proposals. Like contracts, any form of revision must be met with full and voluntary agreement with all parties.

In this paragraph, we present the importance of coordination for team work and also for alliance success. In the rest of this article we will present how coordination is involved in the continuous improvement of the alliance governance.

\section{Cooperation - coordination relationship}

A review of cooperation and coordination related research so far has shown that most studies consider cooperation and coordination issues in isolation from each other (Gulati and Al, 2012), or tend to do not difference between them (Dameron 2003). A better cooperation is assumed to lead to higher performance independent of coordination efforts and vice versa (Das and Al., 1998; Heath and Al., 2000).

A few recent studies, however, have begun to examine how cooperation and coordination issues interrelate, how they independently or jointly impact the alliance' results. Some studies point the possibility that cooperation and coordination-related relationship characteristics shape performance interactively rather that independently (Luo, 2002; Achelhi and A1., 2006, 2007). Other studies have suggested that cooperation and coordination depend on and influence each other and have a joint impact on alliance outcomes that exceeds their combined individual impacts (Kretschmer and Al., 2008). 
Achelhi, H., Truchot, P. (2016). Performance of strategic alliance management: Coordination-cooperation cycle. International Journal of Social Sciences and Education Research, 2 (3), 708-721.

The distinction between cooperation and coordination has been previously used to delineate the understanding facets of collaboration within organizations (Achelhi and Al., 2006, 2007; Gulati, 2007, Gulati 2012)

Neuville (1998) is based on the microsociological approach of inter-individual cooperation in industrial partnerships, differentiates the two concepts in some basic dimensions:

- Coordination is on the prescription plan (« to tell »), it defines an order, a static structure.

- and cooperation on that of action (the « to act»), it is a dynamic process.

Some authors présent that the cooperation is the most advanced form of coordination. (Grossetti et al., 1999; Baudry 1995).

The problem of cooperation (aligning interests) is a problem of motivation, and can be alleviated if not resolved through incentives. In contrast, coordination problems (aligning actions) are fundamentally cognitive in origin, and require shared understanding and common ground to be solved. (Kretschmer and Al., 2008)

Two alternative logics can account for such a super-additive effect: inherent complementarity, which suggests that a change in the extent or quality of cooperation changes the impact of existing coordination efforts and vice versa; and mutual incremental reinforcement, which suggest that a change in the extent or quality of cooperation leads to subsequent changes in coordination efforts and vice versa, resulting in an interactive effect over time. (Gulati and al., 2012)

According to the logic of complementarity, increasing cooperation should enhance the marginal impact of a given level of coordination and vice versa: better cooperation makes any coordination effort more beneficial and vice versa, or in the more specific sense that a particular cooperation provision enhances the effectiveness of a particular coordination mechanism or vice versa.

The complementary effects suggest that cooperation and coordination issues may be intricately interwoven, especially when it comes to adaptiveness. According to reinforcement logic, more extensive cooperation encourages subsequent strengthening of coordination efforts.

\section{Discussion: cooperation-coordination cycle or process.}

Coordination is thinking about the best organization in order to achieve objectives. Coordination is « a set of processes that combine and articulate actions and decisions of different individuals groups to produce a collective result » (N'Gahane et De Ronge, 1996). According to this definition, the coordination objective is the collective purpose satisfaction.

We conclude that coordination is organization's reflexion that seeks the collective efficiency through actions synergy of different partners. 
Achelhi, H., Truchot, P. (2016). Performance of strategic alliance management: Coordination-cooperation cycle. International Journal of Social Sciences and Education Research, 2 (3), 708-721.

Figure 2. Coordination /cooperation cycle.

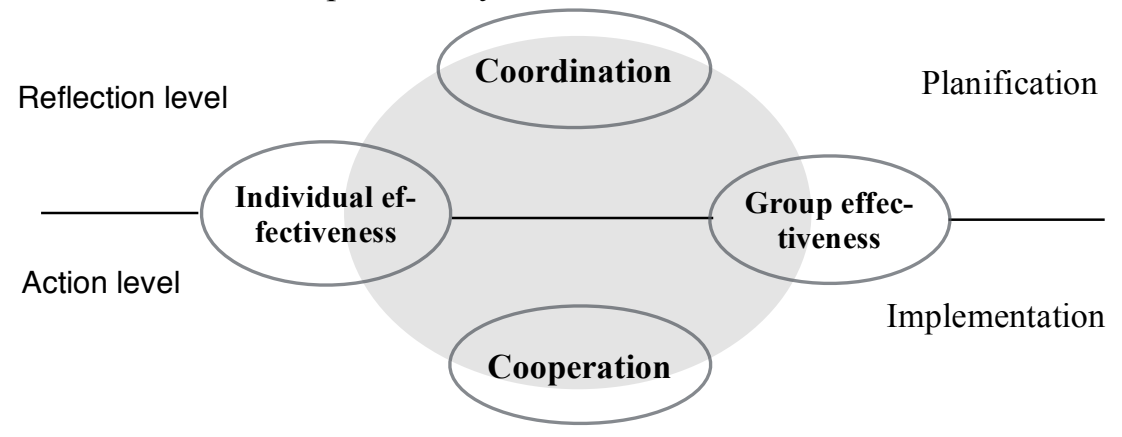

After actions' coordination, participants execute the process, implement the plan: this is the cooperation level. Cooperation begins with the practical implementation of planned actions. Each partner seeks, through cooperation, to realize its own objective. Therefore, through cooperation work, partners seek individual effectiveness through the collective work, which validates our hypothesis1.

After the experience of the collective work, each partner judge the results according to his initial expectations, and seeks a better positioning to maximize its benefit. It happens again by negotiation during a coordination phase: we rethink planning for a better efficiency of collective work, which validates our hypothesis2.

\section{Conclusion}

Depending on our literature search, we are the first researchers who discussed the cooperationcoordination process in strategic alliances. Achelhi and al., (2007) present complementarity between the two levels of alliances: coordination and cooperation. Coordination is related to planning and thinking of the best solution, cooperation is the implementation of this reflection in reality.

Some authors discuss the synergy between the two concepts. In the case of teamwork, Junyan and al., (2010) discuss the importance of this synergy: « the enterprise's requirement and philosophy and form the high cooperation and coordination synergies to achieve the communal development of the individual and the enterprise and to display the group superiority » (Di Junyan and Al., 2010), which joined Dameron (2003) conclusion. In the case of alliances, Gulati and al., (2012) present the necessity of the synergy " cooperation/coordination synergies would be achieved over time even if no complementarity effects existed at any given moment» (Gulati and al., 2012).

In this work, we present a planned collective work in two levels: coordination which seek the collective success, and cooperation which seek the individual success. Thus, we can schematize this complementarity between coordination and cooperation by a spiral that connects reflection to realization, whose goal is the achievement of alliance objectives. It is a dynamic vision of collective work.

If we are in a win-win relationship, the success probability of the alliance will be Higher, so we can conclude that the alliance success depend on cooperation/coordination quality process. In order to understand the strategic alliances management, it isn't enough to realize an investigation 
Achelhi, H., Truchot, P. (2016). Performance of strategic alliance management: Coordination-cooperation cycle. International Journal of Social Sciences and Education Research, 2 (3), 708-721.

or having a database general study. They may reveal and confirme only explicit knowledge. For understanding and shed light on tacit knowledge, it is imperative to do a research action study, or at least a longitudinal study. This method led us to delve deeply on the machinery of alliances management.

The authors of this article elaborate and managed Two Erasmus European project in ordre to transfer competences on innovation. This projects are between universities from UE and Maghreb.

Table1. Projects descriptive card

\begin{tabular}{|c|c|c|}
\hline Project & A & B \\
\hline Objetif & Transfer innovation competences & Students Entrepreneurship \\
Pilote Origine & UE (France) & Maghreb (Morocco) \\
\hline Budget & 1,47 million euros & 1,23 million euros \\
\hline
\end{tabular}

During this experience, we will study hypotheses:

Hyp 1. A planned collective work has two levels: coordination seek the collective success, and cooperation seek the individual success.

Hyp 2: the alliance success depend on cooperation/coordination quality process

Hyp 3: to achieve the goals of the alliance, it is necessary that the coordination/cooperation cycle goes through the different hierarchical levels of the various organizations involved in the relationship.

The fact that the pilots of the two projects are from different cultures, we hope we can also study the impact of the culture on the governance of alliances. Otherwise, this may be a limitation of our study.

A second limitation of our study is our freedom of action: because projects must respect the framework of the European project, the freedom of action is limited by the constraints imposed by the EU.

\section{References}

Achelhi H., Truchot P., Aoussat A. (2007). Dashbord of emergence of cooperation between companiesTechnopôlis case-study. International Conference for the International Association of Management of Technology- Miami.

Achelhi H. and Truchot (2013) « Cooperation between European and Maghreb universities: case study » 22nd International Conference for the International Association of Management of Technology

Anand BN, Khanna T. (2000). « Do firms learn to create value? The case of alliances ». Strategic Management Journal, March Special Issue 21: 295-315.

Ahuja, G. (2000). « Collaboration networks, structural holes, and innovation: A longitudinal study ». Administrative Science Quarterly, 45: 425-455.

Ahuja, G. (2000). « The duality of collaboration: Inducements and opportunities in the formation of interfirm linkages » Strategic Management Journal, 21: 317-343. 
Achelhi, H., Truchot, P. (2016). Performance of strategic alliance management: Coordination-cooperation cycle. International Journal of Social Sciences and Education Research, 2 (3), 708-721.

Alvarez, S. A., \& Barney, J. B. (2001). « How entrepreneurial firms can benefit from alliances with large partners ». Academy of Management Executive, 15(1): 139-148.

Anderson, D. \& Merna, A. (2005). Project management is a capital investment process. Journal of Management in Engineering, 21, 173-178.

Argyris, C. and D. Schoen (1978). Organizational Learning: A Theory of Action Perspective. Reading, MA: Addison Wesley.

Bleeke, J. and Ernst, D. (1991). The way to win in cross-border alliances, Harvard Business Review, 69(6), 127-135.

Buckley, P \& casson A, (1988), «A theory of co-operation in a competitive industry: SEMATECH and semiconductor industry», Academy of management Journal, 38, 113-151

Callahan, J., \& MacKenzie, S. (1999). « Metrics for strategic alliance control ». R\&D Management, 29: 365-377.

Cassar A. (2005) « Coordination and Cooperation in Local, Random and Small World Networks: Experimental Evidence »

Coase, R.H. 1937 « the nature of the firm » reprinted in G.J. Stigler and K.E. Goulding (eds.)

Consoli A. , Tweedale J. and Jain L.,(2007) « The link between agent coordination and cooperation » Springer

Coughlan P., \& Coughlan D., (2002). « Action research for operations management » . International Journal of Operations \& Production Management,Vol. 22 No. 2, pp. 220-240)

Cullen, J. B., Johnson, J. L., \& Sakano, T. (2000). « Success through commitment and trust: The soft side of strategic alliance management ». Journal of World Business, 35: 223-240

Dameron, Stéphanie; Joffre, Olivier (2005) « Rapports coopératifs et confrontation culturelle : le cas de la gestion post fusion Orange- France Télécom Mobiles » — Finance Contrôle Stratégie pp 51-76

Das, T., \& Teng, B. (1999). « Managing risks in strategic alliances ». Academy of Management Executive, 13(4): 50-62.

Das, T. K., \& Teng, B.-S. (2000). « A resource-based theory of strategic alliances ». Journal of Management, 26: 31-61.

Dave Luvison, Michelle A. Marks, (2013) Team coordination in strategic alliances: identifying conditions that reduce team willingness to cooperate -- J. Strategic Business Alliances, Vol. 3, No. 1.

Dess, G. G., \& Shaw, J. D. (2001). « Voluntary turnover, social capital, and organizational performance ». Academy of Management Review, 26. 446-456.

Dincer Omer, Tatoglu Ekrem and Glaister Keith W. (2006). «The strategic planning process: evidence from Turkish firms » Management Research News. Vol. 29 No. 4, 2006 - pp. 206-219

Doh, J. P. 2000. Entrepreneurial privatization strategies: Order of entry and local partner collaboration as sources of competitive advantage. Academy of Management Review, 25: 551-571.

Doz, Y.L., Olk, P.M., Ring, P.S., (2000). Formation processes of R\&D consortia: which path to take: where does it lead? Strategic Management Journal 21, 239-266.

Doz, Yves (1996) « the evolution of cooperation in strategic alliances: initial conditions or learning processes? » Strategic Management Journal, Special Issue, 17: 55-83.

Doz, Y.L. and Hamel, G. (1998). Alliance Advantage: The Art of Creating Value Through Partnering, Harvard Business School Press, Boston 
Achelhi, H., Truchot, P. (2016). Performance of strategic alliance management: Coordination-cooperation cycle. International Journal of Social Sciences and Education Research, 2 (3), 708-721.

Dyer, J. H., Kale, P., \& Singh, H. (2001). « How to make strategic alliances work ». Sloan Management Review, 42(4): 37-43.

DyReyes J. (2008), « Strategic Project Management: Aligning Strategic Business Objectives with Project Management Strategy » for the degree of Master of Science - Applied Information Management and the Graduate School of the University of Oregon

Eisenhardt, K.M., (1989). « Building theories from case study research ». Academy of Management Review $14,532-550$.

Eisenhardt, K. and C. B. Schoonhoven, 1996, "Resource- based view of strategic alliance formation: Strategic and social effects in entrepreneurial firms". Organization Science 7: 136-150.

Enright, M.J., Roberts, B.H., (2001). « Regional clustering in Australia ». Australian Journal of Management $26(1), 65-86$.

Gerhard, T., \& Odenthal, S. (2001). « Alliance management: Challenges for old and new economy companies ». Paper presented during the 21st Annual Strategic Management Society conference

Gomes-Casseres, B. (1994). « Group versus Group: How Alliances Networks Compete », Harvard Business Review, 72(4), 62-74.

Gulati, R. (1998) «Alliances and networks. » Strategic Management Journal, 19, 293 - 317.

Gulati, R. (1999). « Network location and learning: The influence of network resources and firm capabilities on alliance formation ». Strategic Management Journal, 20: 397-420.

Gulati, R and Harbir Singh (1998), « the architecture of cooperation: managing Coordination Costs and Appropriation Concerns in Strategic Alliances » Administrative Science Quaterly, Vol 43, $\mathrm{n}^{\circ} 4,781$ 814

Gulati, R., Nohria, N., \& Zaheer, A. (2000). « Strategic networks ». Strategic Management Journal, 21(Special issue): 199-201.

Gulati, R., T. Khanna and N. Nohria (1994). «Unilateral commitments and the importance of process in alliances ». Sloan Management Review, 35 (3), pp. 61-69.

Gulati, R., 2007, Managing network resources: Alliances, affili- ations, and other relational assets. New York: Oxford Uni- versity Press.

Hageddom, J. (1993) « Understanding the rationale of strategic technology partnering: inter-organizational modes of cooperation and sectoral differences ». Strategic management Journal, 14, 371-385.

Hagedoorn, J. (1995). « A note on international market leaders and networks of strategic technology partnering ». Strategic Management Journal, 16: 214-250

Hamel, G. Doz,Y.L. and Prahalad, C.K. (1989). « Collaborate with Your Competitors- and win » Harvard business review, 67(1), 133-139.

Hamel G. (1991). « Competition for competence and inter-partner learning within international strategic alliances. Strategic Management Journal, 12, 83-103

Harrigan, Kathryn R. (1986), « Managing for Joint Ventures Success. Lexington, MA: Lexington Books.

Hennart, J.F., (1988). «A transaction cost theory of joint ventures ». Strategic Management Journal, JulyAugust, 361-374.

Hennart, J. (1991). « The transaction costs theory of joint ventures: An empirical study of Japanese subsidiaries in the United States ». Management Science, 37: 483-497. 
Achelhi, H., Truchot, P. (2016). Performance of strategic alliance management: Coordination-cooperation cycle. International Journal of Social Sciences and Education Research, 2 (3), 708-721.

Heracleous, L. (2003). Strategy and organization: Realizing strategic management. Cambridge: University Press.

Hoang H, Rothaermel FT. 2005. The effects of general and partner-specific experience on joint R\&D project performance. Academy of Management Journal 48(2): 332 - 345.

Ingham, M., \& Mothe, C. (1998), « How to learn in R\&D partnerships ». R\&D Management, 28, $249-261$.

Inkpen, A.C., (1998), « learning, knowledge acquisition, and strategic alliances » European Management journal, 16, 223-229

Ireland RD, Hitt MA, Vaidyanath D. (2002). « Alliance management as a source of competitive advantage ». Journal of Management 28(3): 413-446.

Inkpen, A. C. (2000). « A note on the dynamics of learning alliances: Competition, cooperation, and relative scope ». Strategic Management Journal, 21. 775-779.

Junyan Di, Ye Jinfu, and Qin Yan. (2010) « Analysis of Enterprise Ideological and Political Education System: the Foundation of the Enterprise Internal Image Management."

Kale, P., Singh, H., \& Perlmutter, H. (2000) « Learning and protection of proprietary assets in strategic alliances: Building relational capital » Strategic Management Journal, 21(Special issue): 217-237.

Kale P, Dyer JH, Singh H. (2002). « Alliance capability, stock market response and long-term alliance success: the role of the alliance function ». Strategic Management Journal 23(8): 747-767.

Kale P, Singh H. (2007) « Building firm capabilities through learning: the role of the alliance learning process in alliance capability and firm-level alliance success ». Strategic Management Journal 28(10): 981-1000.

Khanna, T., Gulati, R., \& Nohria, N. (1998) « The dynamics of learning alliances: Competition, cooperation and relative scope ». Strategic Management Journal, 19: 193-210.

Kannan Srikanth, Phanish Puranam (2014) The Firm as a Coordination System: Evidence from Software Services Offshoring - Organization Science- Vol. 25, No. 4, July-August 2014, pp. 1253-1271

Kumar, S., \& Seth, A. (1998) « The design of coordination and control mechanisms for managing joint venture-parent relationships ». Strategic Management Journal, 19: 579-599.

Kretschmer, T., \& Puranam, P. (2008). « Integration through incentives within differentiated organizations ». Organization Science, 19(6): 860-875

Kannan Srikanth, Phanish Puranam (2014) «The Firm as a Coordination System: Evidence from Software Services Offshoring » Organization Science- Vol. 25, No. 4, July-August, pp. 1253-1271

Kogut, B., \& Zander, U. (1993). « Knowledge of the firm and the evolutionary theory of the multinational corporation ». Journal of International Business Studies, 24(3): 625-645.

Kogut, B., (1988). « Joint ventures, theoritical and empirical pespectives ». Strategic Management Journal, 9, 319-322

R. Leus, G. Wullink, E.W. Hans, Herroelen W, (2003). « A hierarchical approach to multi-project planning under uncertainty » Omega, Volume 35, Issue 5, October 2007, Pages 563-577

Luo, Y. (2008). « Procedural fairness and interfirm cooperation in strategic alliances ». Strategic Management Journal, 29(1): 27-46.

Mário Franco (2011) « Determining factors in the success of strategic alliances: an empirical study performed in Portuguese firms ». European Journal International Management, Vol. 5, No. 6. 
Achelhi, H., Truchot, P. (2016). Performance of strategic alliance management: Coordination-cooperation cycle. International Journal of Social Sciences and Education Research, 2 (3), 708-721.

Chandler, Alfred D. (1977), the visible hand: the managerial revolution in American business. Cambridge, MA: Harvard University Press.

McCalman, J. and Jack R. Meredith, (1990). « Conducting case study research in operations management ». Journal of Operations Management, vol. 11, 239-256.

McEvily, B., Perrone, V., \& Zaheer, A. (2003) « Trust as an organizing principle », Organization Science, 14(1): 91-103.

Meredith J., (1998) « Building operations management theory through case and field research », Journal of Operations Management, vol. 16, 441-454.

Mintzberg H. (1980), Structure in Fives: Designing Effective Organizations

Mothe C., Quelin B.V., (2001). « Ressource creation and partenrship in R\&D consortia » Journal of high technology Management research, 12, 113-138.

Neuville, Jean-Philippe (1998), « La tentation opportuniste. Figures et dynamique de la coopération interindividuelle dans le partenariat industriel ». Revue française de sociologie, Vol 39, num 1, 71-103.

Pisano, G.P., Michael V. Russo, David Teece (1988) « joint ventures and collaborative agreements in the telecommunications equipment industry » In David Mowery (ed.), International Collaborative ventures in U.S. manufacturing: 23-70. Cambridge.

Sakakibara, M. (1997) «Evaluating government-sponsored R\&D consortia in japan: who benefits and how? » Research Policy 26, 447-473.

Srikanth K., Puranam P. (2014) «The Firm as a Coordination System: Evidence from Software Services Offshoring » Organization Science- Vol. 25, No. 4, July-August 2014, pp. 1253-1271

Srivannaboon, S. and Milosevic, D. (2006). A two-way influence between business strategy and project management. International Journal of Project Management, 24, 493-505.

Stanleigh, M. (2006). From crisis to control: New standards for project management. Ivey Business Journal, $70,1-4$.

Stuart, T. E. (2000). « Interorganizational alliances and the performance of firms: A study of growth and innovation rates in a high-technology industry ». Strategic Management Journal, 21: 791-811.

Simonin BL. 1997. The importance of collaborative know-how: an empirical test of the learning organization. Academy of Management Journal 40(5): 1150 - 1175.

Tapinos, E., Dyson, R.G. and Meadows, M. (2005), “The impact of performance measurement in strategic planning', International Journal of Productivity and Performance Management, Vol. 54 No. 5/6, pp. 370-84.

Teece, D., (1992) « Competition, cooperation, and innovation. Organisational arrangements for regimes of rapid technological progress ». Journal of Economic Behavior and Organization 18, 1-25.

Volberda, H.W. (2004), “Crisis in strategy: fragmentation, integration or synthesis”, European Management Review, Vol. 1 No. 1, pp. 35-42.

Winter, S. (1987) « Steiner problem in networks », A survey-Networks, Vol 17, issue 2, 129-167.

Yin, R.K., (1984). Case Study Research: Design and Methods. Sage, Newbury Park, California.

Yin, R.K, (1989). Case Study Research: Design and Methods. Sage Publications, Newbury Park, CA, rev. edn.

Zook, C. (2007), Finding Your Next Core Business, Harvard Business Review, 85(4), pp.66-75 